\title{
Peningkatan Kemampuan Pemecahan Masalah Matematis Siswa melalui Pembelajaran Berbasis Masalah
}

\author{
Tina Sri Sumartini \\ STKIP Garut
}

\begin{abstract}
ABSTRAK
Penelitian ini dilatarbelakangi oleh hasil-hasil penelitian terdahulu yang menunjukkan bahwa kemampuan pemecahan masalah matematis siswa belum sesuai dengan yang diharapkan. Salah satu pembelajaran untuk meningkatkan kemampuan pemecahan masalah matematis adalah pembelajaran berbasis masalah. Tujuan penelitian ini adalah untuk mengetahui peningkatan kemampuan pemecahan masalah matematis siswa sebagai akibat dari pembelajaran berbasis masalah. Penelitian ini adalah kuasi eksperimen yang menerapkan dua pembelajaran yaitu pembelajaran berbasis masalah dan pembelajaran konvensional. Populasi dalam penelitian ini adalah siswa di salah satu SMK di Kabupaten Garut. Pengambilan sampel dilakukan secara purposive sampling, dan diperoleh dua kelas sebagai sampel penelitian. Instrumen penelitian yang digunakan adalah tes kemampuan pemecahan masalah matematis. Berdasarkan hasil analisis tersebut diperoleh kesimpulan bahwa: (1) peningkatan kemampuan pemecahan masalah matematis siswa yang mendapat pembelajaran berbasis masalah lebih baik daripada siswa yang mendapat pembelajaran konvensional, (2) Kesalahan-kesalahan yang dilakukan oleh siswa ketika mengerjakan soal-soal yang berkaitan dengan kemampuan pemecahan masalah matematis adalah kesalahan karena kecerobohan atau kurang cermat, kesalahan mentransformasikan informasi, kesalahan keterampilan proses, dan kesalahan memahami soal.
\end{abstract}

Kata kunci: Pembelajaran Berbasis Masalah, Kemampuan Pemecahan Matematis

\section{ABSTRACT}

This research is motivated by the results of previous studies that showed that students' mathematical problem solving ability is not as expected. One lesson to improve mathematical problem solving is based learning problems. The purpose of this study was to determine the increase in students' mathematical problem solving ability as a result of problem-based learning. This study is a quasi-experimental study that applies two problem-based learning and conventional learning. The population in this study were students in one of the vocational schools in Garut. Sampling was done by purposive sampling, and obtained two classes as the study sample. The research instrument used was a test of mathematical problem solving abilities. Based on these results we concluded that: (1) the increase in students' mathematical problem solving ability that gets problem-based learning better than students who received conventional learning, (2) mistakes made by student when working on the problems related to mathematical problem solving ability was a mistake due to carelessness or less closely, tansform fault information, error process skills, and misunderstanding question.

Keywords: problem based learning, mathematical problem solving ability

\section{PENDAHULUAN}

Matematika memiliki peranan penting dalam segala aspek kehidupan terutama dalam meningkatkan daya pikir manusia, sehingga matematika merupakan salah satu mata pelajaran yang diwajibkan di setiap jenjang sekolah mulai dari SD sampai SMA. Menurut Abdurrahman (2003) "Matematika adalah bahasa simbolis yang fungsi praktisnya untuk mengekspresikan hubungan-hubungan kuantitatif dan keruangan sedangkan fungsinya adalah untuk memudahkan berpikir".

Dalam pendidikan, kemampuan siswa diasah melalui masalah, sehingga siswa mampu meningkatkan berbagai kompetensi yang dimilikinya. Hal ini sesuai dengan Dahar (2011: 121) yang menyatakan bahwa 
kemampuan untuk memecahkan masalah pada dasarnya merupakan tujuan utama proses pendidikan.

Berdasarkan penelitian sebelumnya, prestasi siswa SMK dalam pembelajaran matemtika masih tergolong rendah terutama dalam hal kemampuan memecahkan masalah matematis. Dari data yang diperoleh, sebanyak $73 \%$ siswa masih memiliki kemampuan pemecahan masalah yang relatif kurang. Hal ini disebabkan oleh beberapa hal yang diantaranya siswa kurang berminat dalam pembelajaran matematika, proses pembejaran yang masih mengandalkan guru sebagai pemberi seluruh informasi materi matematika, dan sarana pembelajaran yang masih kuraang.

Jika dilihat dari aspek kurikulum, kemampuan pemecahan masalah menjadi salah satu tujuan dalam pembelajaran matematika di sekolah yaitu melatih cara berpikir dan bernalar dalam menarik kesimpulan, mengembangkan kemampuan memecahkan masalah, serta mengembangkan kemampuan menyampaikan informasi atau mengkomunikasikan ide-ide melalui lisan, tulisan, gambar, grafik, peta, diagram, dan sebagainya (Depdiknas, 2006: 6). Sejalan dengan tujuan pembelajaran matematika yang terdapat dalam KTSP (dalam Depdiknas 2006), peserta didik harus memiliki kemampuan memecahkan masalah yang meliputi kemampuan memahami masalah, merancang model matematika, menyelesaikan model dan menafsirkan solusi yang diperolah.

Kemampuan pemecahan masalah sangat penting dimiliki oleh setiap siswa karena (a) pemecahan masalah merupakan tujuan umum pengajaran matematika, (b) pemecahan masalah yang meliputi metoda, prosedur dan strategi merupakan proses inti dan utama dalam kurikulum matematika, dan (c) pemecahan masalah merupakan kemampuan dasar dalam belajar matematika (Branca, 1980). Selain itu, Ruseffendi (1991: 103) mengatakan bahwa kemampuan pemecahan masalah sangat penting dalam matematika, bukan saja bagi mereka yang dikemudian hari akan mendalami atau mempelajari matematika, melainkan juga bagi mereka yang akan menerapkannya dalam bidang studi lain dan dalam kehidupan sehari-hari

Berkenaan dengan pentingnya kemampuan pemecahan masalah, National Council of Teacher of Mathematics (NCTM, 2000) mengatakan bahwa dalam pelaksanaan pembelajaran matematika di sekolah, guru harus memperhatikan lima kemampuan matematika yaitu: koneksi (conections), penalaran (reasoning), komunikasi (communications), pemecahan masalah (problem solving), dan representasi (representations). Oleh karena itu, guru memiliki peranan yang sangat penting dalam menumbuhkan kemampuan pemecahan masalah matematis dalam diri siswa baik dalam bentuk metode pembelajaran yang dipakai, maupun dalam evaluasi berupa pembuatan soal yang mendukung.

Meningkatkan kemampuan pemecahan masalah matematis siswa perlu didukung oleh metode pembelajaran yang tepat sehingga tujuan pembelajaran dapat tercapai. Wahyudin (2008) mengatakan bahwa salah satu aspek penting dari perencanaan bertumpu pada kemampuan guru untuk mengantisipasi kebutuhan dan materi-materi atau modelmodel yang dapat membantu para siswa untuk mencapai tujuan pembelajaran. Didukung pula oleh Sagala (2011) bahwa guru harus memiliki metode dalam pembelajaran sebagai strategi yang dapat memudahkan peserta didik untuk menguasai ilmu pengetahuan yang diberikan. Selain itu, guru harus mengetahui kesulitan-kesulitan yang dialami siswa dalam pembelajaran matematika sehingga dapat diberikan solusi yang tepat agar tujuan dalam pembelajaran dapat tercapai.

Salah satu pembelajaran yang diduga dapat meningkatkan kemampuan 
memecahkan masalah matematis siswa adalah pembelajaran berbasis masalah. Pembelajaran berbasis masalah (problem based learning) adalah suatu pembelajaran yang menggunakan masalah dunia nyata sebagai suatu konteks bagi peserta didik untuk belajar tentang cara berpikir kritis dan keterampilan pemecahan masalah serta untuk memperoleh pengetahuan dan konsep yang esensial dari materi pembelajaran (Nurhasanah, 2009: 12). Menurut Arends (2008: 43) pembelajaran berbasis masalah (problem based learning) dirancang terutama untuk membantu siswa mengembangkan keterampilan berpikir, keterampilan menyelesaikan masalah, dan keterampilan intelektualnya.

Adapun karakteristik dari pembelajaran berbasis masalah (problem based learning) adalah (1) ketergantungan pada masalah, masalahnya tidak mengetes kemampuan, dan masalah tersebut membantu pengembangan kemampuan itu sendiri, (2) masalahnya benar-benar ill-structured, tidak setuju pada sebuah solusi, dan ketika informasi baru muncul dalam proses, presepsi akan masalah dan solusi pun dapat berubah, (3) siswa menyelesaikan masalah, guru bertindak sebagai pelatih dan fasilitator, (4) siswa hanya diberikan petunjuk bagaimana mendekati masalah dan tidak ada suatu formula bagi siswa untuk mendekati masalah, dan (5) keaslian dan penampilan.

Berdasarkan latar belakang masalah di atas, maka rumusan masalah dalam penelitian ini secara umum adalah: "Apakah pembelajaran berbasis masalah dapat meningkatkan kemampuan pemecahan masalah matematis siswa?". Secara lebih khusus rumusan masalah di atas dibuat sub masalah sebagai berikut:

1. Apakah kemampuan pemecahan masalah matematis siswa yang mendapatkan pembelajaran berbasis masalah lebih baik daripada siswa yang mendapatkan

pembelajaran

konvensional?

2. Kesalahan-kesalahan apa yang dilakukan siswa ketika mengerjakan soal-soal kemampuan pemecahan masalah matematis?

Sebagaimana telah diuraikan di atas, kemampuan pemecahan masalah matematis siswa sangat penting dalam pembelajaran matematika, maka hasil penelitian ini dapat memberi manfaat sebagai berikut:

1. Bagi guru, pembelajaran berbasis masalah memberikan alternatif yang dapat diterapkan dalam pembelajaran matematika untuk meningkatkan kemampuan pemecahan masalah matematis siswa.

2. Bagi siswa, memberikan kesan baru dalam pembelajaran matematika dan memudahkan siswa untuk memahami konsep matematika sehingga terjadi peningkatan kemampuan pemecahan masalah matematis siswa.

3. Bagi peneliti, memberikan pengalaman yang berharga untuk membangun inovasi dalam dunia pendidikan melalui pembelajaran yang efektif dalam meningkatkan kemampuan pemecahan masalah matematis siswa.

4. Bagi dunia pendidikan, dapat memberikan sumbangan pemikiran tentang pembelajaran yang dapat meningkatkan kualitas pendidikan

\section{Kemampuan Pemecahan Masalah Matematis}

Pemecahan masalah merupakan suatu proses untuk mengatasi kesulitan-kesulitan yang dihadapi untuk mencapai tujuan yang diharapkan. Dalam matematika, kemampuan pemecahan masalah harus dimiliki oleh siswa untuk menyelesaikan soal-soal berbasis masalah. Menurut Sumarmo (2000) pemecahan masalah adalah suatu proses 
untuk mengatasi kesulitan yang ditemui untuk mencapai suatu tujuan yang diimginkan.

Branca (dalam Sumarmo, 1994) mengatakan bahwa pemecahan masalah dapat diartikan dengan menggunakan interpretasi umum, yaitu pemecahan masalah sebagai tujuan, pemecahan masalah sebagai proses, dan pemecahan masalah sebagai keterampilan dasar. Pemecahan masalah sebagai tujuan menyangkut alasan mengapa matematika itu diajarkan. Dalam interpretasi ini, pemecahan masalah bebas dari soal, prosedur, metode atau isi khusus yang menjadi pertimbangan utama adalah bagaimana cara menyelesaikan masalah yang merupakan alasan mengapa matematika itu diajarkan. Pemecahan masalah sebagai proses merupakan suatu kegiatan yang lebih mengutamakan pentingnya prosedur, langkah-langkah strategi yang ditempuh oleh siswa dalam menyelesaikan masalah dan akhirnya dapat menemukan jawaban soal bukan hanya pada jawaban itu sendiri.

Bell (1978: 119) menyatakan bahwa terdapat lima strategis yang berkaitan dengan pemecahan masalah dunia nyata (real world) yaitu: (1) menyajikan masalah dalam bentuk yang jelas sehingga tidak bermakna ganda; (2) menyatakan masalah dalam bentuk yang jelas sehingga tidak bermakna ganda; (3)menyusun hipotesi-hipotesis alternatif dan prosedur yang diperkirakan dapat dipergunakan untuk memecahkan masalah tersebut; (4) menguji hipotesis dan melakukan kerja untuk memperoleh solusi (pengumpulan data, pengolahan data, dll), solusi yang diperoleh mungkin lebih dari satu; (5) jika diperoleh satu solusi maka langkah selanjutnya memeriksa kembali apakah solusi itu benar namun jika diperoleh lebih dari satu solusi maka memilih solusi mana yang paling baik.

Olkin dan Schoenfeld (Sumarmo, 2013: 447) menyatakan bahwa bentuk soal pemecahan masalah yang baik hendaknya memiliki karakteristik sebagai berikut: (1) dapat diakses tanpa banyak menggunakan mesin, ini berarti masalah yang terlibat bukan karena perhitungan yang sulit; (2) dapat diselesaikan dengan beberapa cara, atau bentuk soal yang open ended; (3) melukiskan ide matematika yang penting (matematika yang bagus); (4) tidak memuat solusi dengan trik; (5) dapat diperluas dan digeneralisasikan (untuk memperkaya eksplorasi).

Sumarmo (2013: 128) menyatakan bahwa pemecahan masalah matematik mempunyai dua makna yaitu: (1) pemecahan masalah sebagai suatu pendekatan pembelajaran, yang digunakan untuk menemukan kembali (reinvention) dan memahami materi, konsep, dan prinsip matematika. Pembelajaran diawali dengan penyajian masalah atau situasi yang kontekstual kemudian melalui induksi siswa menemukan konsep/prinsip matematika; (2) sebagai tujuan atau kemampuan yang harus dicapai, yang dirinci menjadi lima indikator, yaitu:

1. mengidentifikasi kecukupan data untuk pemecahan masalah;

2. membuat model matematik dari suatu situasi atau masalah sehari-hari dan menyelesaikannya;

3. memilih dan menerapkan strategi untuk menyelesaikan masalah matematika dan atau di luar matematika;

4. menjelaskan atau menginterpretasikan hasil sesuai permasalahan asal, serta memeriksa kebenaran hasil atau jawaban;

5. menerapkan matematika secara bermakna.

Selain itu, Polya (dalam Ruseffendi, 1991) mengemukakan bahwa untuk memecahkan suatu masalah ada empat langkah yang dapat dilakukan, yakni:

1. Memahami masalah.

Kegiatan dapat yang dilakukan pada langkah ini adalah: apa (data) yang diketahui, apa yang tidak diketahui (ditanyakan), apakah informasi cukup, kondisi (syarat) apa yang 
harus dipenuhi, menyatakan kembali masalah asli dalam bentuk yang lebih operasional (dapat dipecahkan).

2. Merencanakan pemecahannya.

Kegiatan yang dapat dilakukan pada langkah ini adalah: mencoba mencari atau mengingat masalah yang pernah diselesaikan yang memiliki kemiripan dengan masalah yang akan dipecahkan, mencari pola atau aturan, menyusun prosedur penyelesaian (membuat konjektur).

3. Menyelesaikan masalah sesuai rencana.

Kegiatan yang dapat dilakukan pada langkah ini adalah: menjalankan prosedur yang telah dibuat pada langkah sebelumnya untuk mendapatkan penyelesaian.

4. Memeriksa kembali prosedur dan hasil penyelesaian.

Kegiatan yang dapat dilakukan pada langkah ini adalah: menganalisis dan mengevaluasi apakah prosedur yang diterapkan dan hasil yang diperoleh benar, atau apakah prosedur dapat dibuat generalisasinya.

Indikator pemecahan masalah matematis dalam penelitian ini adalah: (1) memahami masalah dan merencanakan pemecahan masalah; (2) membuat proses penyelesaian suatu masalah; (3) menjelaskan atau menginterpretasikan hasil sesuai permasalahan asal, serta memeriksa kebenaran hasil atau jawaban.

\section{Pembelajaran Berbasis Masalah}

Pembelajaran berbasis masalah dalam bahasa Inggris diistilahkan problem based learning (PBL) pertama kali diperkenalkan pada awal tahun 1970-an sebagai salah satu upaya menemukan solusi dalam diagnosa dengan membuat pertanyaan-pertanyaan sesuai situasi yang ada. Duch (2001) mendefinisikan bahwa pembelajaran berbasis masalah merupakan pendekatan pembelajaran yang mempunyai ciri menggunakan masalah nyata sebagai konteks bagi siswa untuk belajar berpikir kritis, keterampilan pemecahan masalah, dan memperoleh pengetahuan mengenai esensi materi pembelajaran.

Mengacu dari pendapat Duch maka pembelajaran berbasis masalah merupakan pembelajaran yang menuntut aktivitas mental siswa secara optimal dalam belajar berpikir kritis, keterampilan pemecahan masalah, dan memperoleh pengetahuan mengenai esensi dari materi pelajaran dalam memahami suatu konsep, prinsip, dan keterampilan matematis siswa berbentuk ill-stucture atau open-ended melalui stimulus.

Pembelajaran berbasis masalah memiliki sepuluh karakteristik utama yang harus dipenuhi sebagaimana yang dikemukakan oleh Amir (2009) yaitu: sebagai berikut:

1. permasalahan menjadi starting point dalam belajar;

2. permasalahan yang diangkat adalah permasalahan yang ada di dunia nyata yang tidak terstruktur;

3. permasalahan membutuhkan perspektif ganda (multi perspective);

4. permasalahan menantang pengetahuan yang dimiliki oleh siswa sikap dan kompetensi yang kemudian membutuhkan identifikasi kebutuhan belajar dan bidang baru dalam belajar;

5. belajar pengarahan diri menjadi hal yang utama;

6. pemanfaatan sumber pengetahuan yang beragam penggunaannya dan evaluasi sumber informasi merupakan proses yang esensial dalam PBM;

7. belajar adalah kolaboratif, komunikasi, kooperatif;

8. pengembangan keterampilan inkuiri dan pemecahan masalah sama pentingnya dengan penguasaan isi pengetahuan untuk mencari solusi dari sebuah permasalahan;

9. keterbukaan proses dalam PBM meliputi sintesis dan integrasi dari sebuah proses belajar; 
10. PBM melibatkan evaluasi dan review pengalaman dan proses belajar.

Selain itu, Barrett (2005 : 15) merumuskan ciri PBL sebagai berikut:

1. Mula-mula masalah diberikan kepada siswa.

2. Siswa mendiskusikan masalah itu dalam kelompok. Mereka mengklarifikasi fakta, mendefinisikan apa masalahnya. Menggali gagasan berdasarkan pengetahuan sebelumnya. Menemukenali apa yang mesti diketahui (dipelajari) untuk memecahkan masalah itu (isu belajar terletak di sini). Bernalar melalui masalah dan menentukan apa tindakan atas masalah tersebut.

3. Setiap siswa secara perorangan aktif terlibat mempelajari pengetahuan yang diperlukan untuk menyelesaikan masalah mereka.

4. Bekerja kembali berkelompok untuk menyelesaikan masalah

5. Menyajikan selesaian atas masalah

6. Melihat dan menilai kembali apa yang telah mereka pelajari dari pengalaman memecahkan masalah itu.

Menurut Barrett, agar berhasil, seorang fasilitator yang menggunakan PBL sebagai pendekatan pembelajaran mestilah:

1. Tertarik dan antusias

2. Melupakan ceramah

3. Menenggang keheningan

4. Membuat siswa berinteraksi satu sama lain

5. Mendorong penggunaan sumber informasi akurat sewaktu siswa menyelidiki isu belajarnya

6. Berorientasi sasaran masalah dan belajar

7. Menciptakan lingkungan belajar yang mendukung untuk kelompok belajar

Menurut Forgarty (Rusman, 2012) langkah-langkah yang akan dilalui oleh siswa dalam sebuah proses PBL/PBM adalah sebagai berikut:

1. menemukan masalah;
2. mendefinisikan masalah;

3. mengumpulkan fakta;

4. menyusun hipotesis;

5. melakukan penyelidikan;

6. menyempurnakan masalah yang telah didefinisikan;

7. menyimpulkan alternatif pemecahan secara kolaboratif; dan

8. melakukan pengujian hasil solusi pemecahan masalah

Adapun langkah-langkah pembelajaran berbasis masalah adalah sebagai berikut:

Tabel 1. Langkah-langkah PBM

\begin{tabular}{|c|c|c|}
\hline Fase & Indikator & Tingkah Laku Guru \\
\hline 1 & $\begin{array}{l}\text { Orientasi } \\
\text { siswa pada } \\
\text { masalah }\end{array}$ & $\begin{array}{l}\text { Menjelaskan tujuan } \\
\text { pembelajaran, menjelaskan } \\
\text { logistik yang diperlukan, } \\
\text { dan memotivasi siswa } \\
\text { terlibat pada aktivitas } \\
\text { pemecahan masalah }\end{array}$ \\
\hline 2 & $\begin{array}{l}\text { Mengorganis } \\
\text { asikan siswa } \\
\text { untuk belajar }\end{array}$ & $\begin{array}{l}\text { Membantu siswa } \\
\text { mendefinisikan dan } \\
\text { mengorganisasikan tugas } \\
\text { belajar yang berhubungan } \\
\text { dengan masalah tersebut }\end{array}$ \\
\hline 3 & $\begin{array}{l}\text { Membimbing } \\
\text { pengalaman } \\
\text { individual/kel } \\
\text { ompok }\end{array}$ & $\begin{array}{l}\text { Mendorong siswa untuk } \\
\text { mengumpulkan informasi } \\
\text { yang sesuai, melaksanakan } \\
\text { eksperimen untuk } \\
\text { mendapatkan penjelasan } \\
\text { dan pemecahan masalah }\end{array}$ \\
\hline 4 & $\begin{array}{l}\text { Mengemban } \\
\text { gkan dan } \\
\text { menyajikan } \\
\text { hasil karya }\end{array}$ & $\begin{array}{l}\text { Membantu siswa dalam } \\
\text { merencanakan dan } \\
\text { menyiapkan karya yang } \\
\text { sesuai seperti laporan, dan } \\
\text { membantu mereka untuk } \\
\text { berbagi tugas dengan } \\
\text { temannya }\end{array}$ \\
\hline 5. & $\begin{array}{l}\text { Menganalisis } \\
\text { dan } \\
\text { mengevaluasi } \\
\text { proses } \\
\text { pemecahan } \\
\text { masalah }\end{array}$ & $\begin{array}{l}\text { Membantu siswa untuk } \\
\text { melakukan refleksi atau } \\
\text { evaluasi terhadap } \\
\text { penyelidikan mereka dan } \\
\text { proses yang mereka } \\
\text { gunakan }\end{array}$ \\
\hline
\end{tabular}

Dari tabel d atas, dapat dilihat bahwa guru mengawali pembelajaran dengan menjelaskan tujuan yang hendak dicapai dalam pembelajaran, mendeskripsikan, dan memotivasi siswa untuk terlibat dalam aktivitas dalam kegiatan mengatasi masalah. 
Berdasarkan masalah yang dipelajari, siswa berusaha untuk membuat rancangan, proses, penelitian yang mengarah ke penyelesaian masalah, sehingga membangun pengetahuan mereka sendiri melalui pengalaman nyata, kemudian siswa mengidentifikasi permasalahan dengan cara mencari apa saja hal-hal yang diketahui, yang ditanyakan, dan mencari cara yang cocok untuk menyelesaikan permasalahan tersebut. Dalam menginvestigasikan dan menyelesaikan masalah, dalam prosesnya siswa menggunakan banyak keterampilan sehingga termotivasi untuk memecahkan masalah nyata dan guru mengapresiasi aktivitas siswa sehingga siswa senang bekerja sama.

Adapun manfaat yang diperoleh melalui PBL menurut Gick dan Holyoak (dalam Krismiati: 2008) antara lain:

\section{Motivasi (Motivation)}

PBL membuat siswa lebih terlibat dalam pembelajaran sebab mereka terikat untuk merespon dan karena mereka merasa diberi kesempatan untuk mendapatkan hasil (dampak) dari penyelidikan.

2. Hubungan dan Isi (Relevance And Context)

PBL menawarkan siswa sebuah jawaban yang jelas terhadap pertanyaan, "Mengapa kita perlu mempelajari informasi ini?", dan "Apa saja dari yang sedang saya lakukan di sekolah harus dilakukan dengan sesuatu dalam dunia nyata?"

\section{Berfikir Tingkat tinggi (Higher-Order}

Thinking)

Skenario masalah yang tidak lengkap memanggil keluar (membangkitkan) berfikir kritis dan kreatif siswa, menebak Apa jawaban yang benar yang dikehendaki guru untuk saya temukan?

4. Pembelajaran bagaimana belajar (Learning How To Learn)

PBL mengembangkan metakognisi dan pembelajaran diri yang teratur dengan meminta siswa untuk menghasilkan cara mereka sendiri mendefinisikan masalah, mencari informasi, menganalisis data dan membuat serta menguji hipotesis, membandingkan strategi lain, dan membaginya dengan siswa lain dan strategi dari pembimbing

5. Keaslian (Authenticity)

PBL melibatkan siswa dalam mempelajari informasi dalam cara yang sama ketika mengingatnya kembali dan menerapkan dalam situasi yang akan datang dan menilai pembelajaran dengan cara mendemonstrasikan pemahaman dan bukan kemahiran belaka.

\section{METODE}

Penelitian yang digunakan adalah kuasi eksperimen. Desain penelitiannya menggunakan desain kelompok kontrol non-ekuivalen.

O X O (Ruseffendi, 2005:53)

$\mathrm{O} \quad \mathrm{O}$

Keterangan:

$\mathrm{O}$ : Tes kemampuan pemecahan masalah matematis siswa

$\mathrm{X}$ : Pembelajaran Berbasis Masalah

... : Pengambilan sampel tidak secara acak

Penelitian ini dilakukan di salah satu SMK di Kabupaten Garut. Penelitian dilaksanakan dari bulan Februari sampai April 2015.

\section{HASIL DAN PEMBAHASAN}

Hasil data yang diperoleh dari pretes, postes, dan N-Gain diolah dengan software SPSS 18 dan microsoft exel 2010 disajikan dalam tabel berikut:

Tabel 2

Statistik Deskriptif Kemampuan Pemecahan Masalah Matematis
\begin{tabular}{|l|c|c|c|c|c|c|}
\hline \multirow{3}{*}{} & \multicolumn{3}{|c|}{ Kelas Eksperimen } & \multicolumn{3}{c|}{ Kelas Kontrol } \\
\cline { 2 - 7 } & $\mathbf{N}$ & $\overline{\bar{X}}$ & $\mathbf{S}$ & $\mathbf{N}$ & $\overline{\mathbf{X}}$ & S \\
\hline Pretes & 36 & 44,03 & 14,032 & 36 & 38,35 & 12,677 \\
\hline Postes & 36 & 71,81 & 15,545 & 36 & 63,61 & 12,283 \\
\hline N-gain & 36 & 0,52 & 0,20 & 36 & 0,36 & 0,18 \\
\hline \multicolumn{7}{|c|}{ Skor Maksimum Ideal: 100} \\
\hline
\end{tabular}

Jurnal "Mosharafa", Volume 5, Nomor 2, Mei 2016

ISSN 20864280 
Berdasarkan tabel di atas, terlihat bahwa ada kenaikan yang signifikan antara kemampuan pemecahan masalah matematis siswa setelah mendapat perlakuan. Siswa pada kelas eksperimen memperoleh rataan yang lebih besar dari kelas kontrol. Besarnya kenaikan rataan untuk kelas eksperimen dari pretes ke postes sebesar 27,78, sedangkan kenaikan rataan untuk kelas kontrol dari pretes ke postes sebesar 25,26. Secara sepintas, gambaran tersebut menunjukkan bahwa kemampuan kemampuan pemecahan masalah matematis siswa pada kelas eksperimen lebih baik dari kelas kontrol. Selain itu, jika dilihat dari peningkatannya, Ngain kelas eksperimen lebih besar dari kelas kontrol, walaupun keduanya diinterpretasikan dalam kategori sedang.

\section{Uji Normalitas}

Tabel 3

Hasil Uji Normalitas Skor Pretes dan Postes Kemampuan Pemecahan Masalah Matematis Siswa

\begin{tabular}{|l|l|c|c|c|}
\hline Hasil & \multirow{2}{*}{ Kelas } & \multicolumn{3}{|c|}{ Shapiro Wilk } \\
\cline { 3 - 5 } & & Statistic & $d f$ & pig \\
\hline \multirow{2}{*}{ Pretes } & Eksperimen & 0,926 & 36 & 0,019 \\
\cline { 2 - 5 } & Kontrol & 0,854 & 36 & 0,000 \\
\hline \multirow{2}{*}{ N-gain } & Eksperimen & 0,879 & 36 & 0,001 \\
\cline { 2 - 5 } & Kontrol & 0,970 & 36 & 0,415 \\
\hline
\end{tabular}

Dari tabel di atas, terlihat bahwa hasil pretes kelas eksperimen dan kelas kontrol memiliki sig < 0,05, sehingga untuk keduanya Ho ditolak artinya skor pretes kemampuan pemecahan masalah matematis siswa kelas eksperimen dan kelas kontrol tidak berdistribusi normal. Untuk hasil n-gain kelas eksperimen memiliki sig < 0,05, maka Ho ditolak artinya skor n-gain kemampuan pemecahan masalah matematis siswa kelas eksperimen tidak berdistribusi normal. Karena kelas kontrol memiliki sig >0,05, maka Ho diterima artinya skor n-gain kemampuan pemecahan masalah matematis siswa kelas kontrol berdistribusi normal. Karena skor pretes kedua kelas tidak beridtribusi normal, maka pengujian hipotesis menggunakan uji nonparametrik yaitu uji Mann Whitney-U. Begitu juga untuk n-gain karena kelas eksperimen berdistribusi tidak normal, maka pengujian hipotesis menggunakan uji nonparametrik yaitu uji Mann Whitney-U.

\section{Uji Kesamaan Rataan Pretes Kemampuan Pemecahan Masalah Matematis}

Tabel 4

Hasil Uji Kesamaan Rataan Skor Pretes

Kemampuan Pemecahan Masalah Matematis Siswa

\begin{tabular}{|c|c|c|}
\hline Statistik & Nilai & Keterangan \\
\hline Mann Whitney U & 584,000 & \multirow{3}{*}{ Ho diterima } \\
\hline Z & $-0,731$ & \\
\hline Asymp. Sig. (2-tailed) & 0,465 & \\
\hline
\end{tabular}

Berdasarkan tabel di atas, diperoleh nilai sig $=0,465$. Karena nilai sig $>0,05$ maka Ho diterima. Hal ini berarti tidak terdapat perbedaan rataan skor pretes kemampuan pemecahan masalah matematis pada kelas eksperimen dan kelas kontrol.

\section{Uji Perbedaan Rataan Skor N-gain Kemampuan Pemecahan Masalah Matematis}

Tabel 5

Hasil Uji Perbedaan Rataan Skor N-gain

Kemampuan Pemecahan Masalah Matematis

\begin{tabular}{|c|c|c|}
\hline Statistik & Nilai & Keterangan \\
\hline Mann Whitney $U$ & 319,000 & \multirow{3}{*}{ Ho ditolak } \\
\hline Z & $-3,715$ & \\
\hline Asymp. Sig. (2-tailed) & 0,000 & \\
\hline
\end{tabular}

Berdasarkan tabel di atas, diperoleh nilai sig $=0,000$. Karena penelitian ini menggunakan uji satu pihak maka nilai sig menjadi 0,000 sehingga sig < 0,05 artinya Ho ditolak. Hal ini berarti peningkatan kemampuan pemecahan masalah matematis siswa yang mendapat pembelajaran berbasis masalah lebih baik daripada siswa yang mendapat pembelajaran konvensional.

Kesalahan-kesalahan yang dilakukan siswa ketika mengerjakan soal-soal kemampuan pemecahan masalah matematis 
1. Kesalahan karena kecerobohan atau kurang cermat

Siswa melakukan kesalahan karena kurang cermat dalam memahami konsep, sehingga salah dalam menuliskan rumus Phytagoras. Seharusnya berdasarkan gambar yang dibuat siswa rumus yang digunakan adalah $b^{2}=a^{2}+c^{2}$. Selain itu, dari hasil pekerjaan siswa di atas, yaitu $576+b^{2}+$ 49 menjadi $b^{2}=576-49$ terlihat jelas siswa melakukan kesalahan yang diakibatkan karena kurang menguasai teknik berhitung. Hal ini dapat dilihat pada gambar berikut:

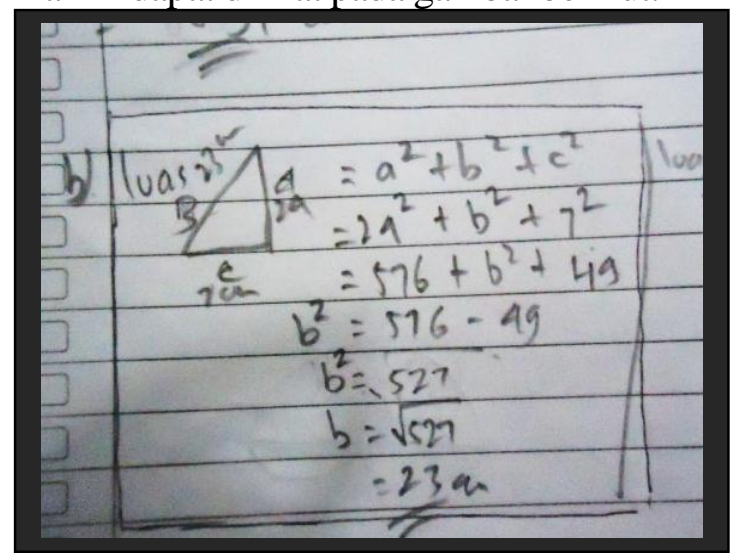

Gambar 1. Kesalahan karena kecerobohan

2. Kesalahan dalam mentransformasikan informasi dalam soal

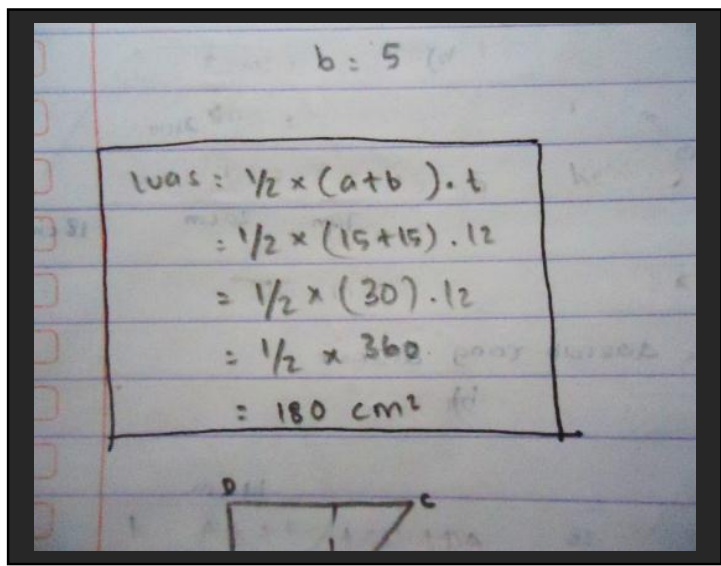

Gambar 2. Kesalahan mentransformasi soal

Dari gambar di atas, terjadi kesalahan siswa dalam memahami soal. Siswa sudah benar dalam menuliskan konsep mengenai luas trapesium, tetapi siswa belum bisa menangkap informasi yang terkandung dalam soal. Siswa salah dalam menuliskan panjang sisi sejajar dalam trapesium yang seharusnya panjang sisi yang satu harus ditambahkan terlebih dahulu dengan panjang bagian yang lain yang pencariannya menggunakan teorema phytagoras.

3. Kesalahan keterampilan proses

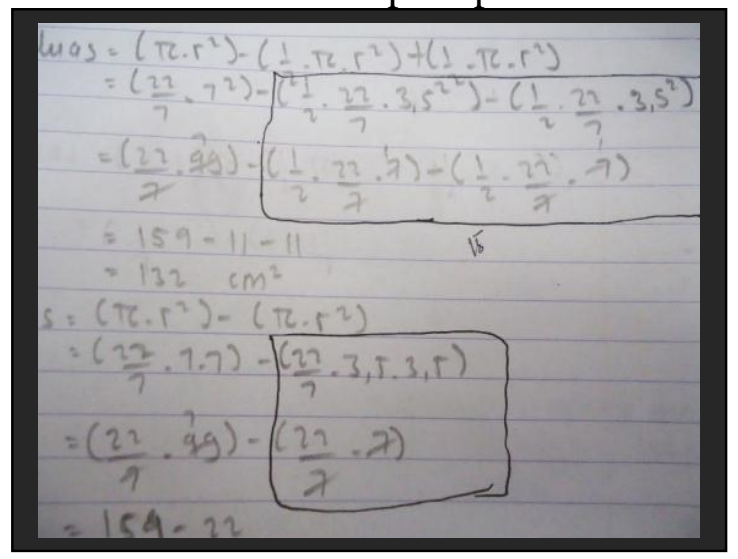

Gambar 3. Kesalahan keterampilan proses

Dari gambar di atas, siswa melakukan kesalahan keterampilan proses. Siswa salah dalam melakukan perhitungan perkalian yaitu $3,5 \times 3,5=7 \quad$ seharusnya $\quad 3,5 \times 3,5=$ 12,25, sehingga menyebabkan jawabannyapun salah. Hal tersebut diakibatkan karena siswa tergesa-gesa dalam melakukan perhitungan.

4. Kesalahan memahami soal

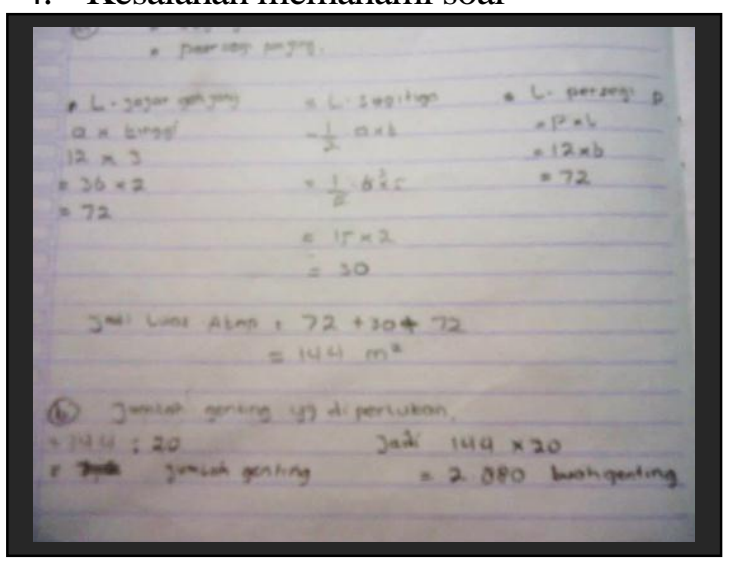

Gambar 4. Kesalahan kesalahan memahami soal

Jurnal "Mosharafa", Volume 5, Nomor 2, Mei 2016

ISSN 20864280 
Dari gambar di atas, siswa melakukan kesalahan dalam memahami soal yaitu menentukan tinggi dari segitiga. Siswa menganggap bahwa segitiga tersebut segitiga siku-siku sehingga langsung menentukan tinggi segitiga $5 \mathrm{~cm}$.

\section{PENUTUP}

\section{Kesimpulan}

1. Peningkatan kemampuan pemecahan masalah matematis siswa yang mendapatkan pembelajaran berbasis masalah lebih baik daripada siswa yang mendapatkan pembelajaran konvensional.

2. Kesalahan-kesalahan yang dilakukan oleh siswa ketika mengerjakan soalsoal yang berkaitan dengan kemampuan pemecahan masalah matematis adalah kesalahan karena kecerobohan atau kurang cermat, kesalahan mentransformasikan informasi, kesalahan keterampilan proses, dan kesalahan memahami soal.

\section{Saran}

Berdasarkan kesimpulan penelitian di atas, diajukan beberapa saran sebagai berikut:

1. Pembelajaran berbasis masalah dapat digunakan sebagai pembelajaran di tingkat SMK dalam upaya meningkatkan kemampuan pemecahan masalah matematis.

2. Perlu dilakukan penelitian lanjutan, untuk melihat keefektifan pembelajaran berbasis masalah pada level sekolah yang berbeda.

3. Pada penelitian ini hanya dikaji peningkatan kemampuan pemecahan masalah matematis secara keseluruhan. Oleh karena itu, diharapkan penelitian selanjutnya dapat mengkaji peningkatan kemampuan pemecahan masalah berdasarkan kemampuan awal siswa baik pada kategori tinggi, sedang, maupun menengah.

4. Dilihat dari kesalahan-kesalahan yang dilakukan oleh siswa, sebaiknya setiap pembelajaran, guru selalu mengevaluasi hasil pekerjaan siswa terutama jika ada kesalahan konsep sehingga bisa diluruskan pada pertemuan berikutnya

\section{DAFTAR PUSTAKA}

Abdurrahman, Mulyono. (2003). Pendidikan Bagi Anak Berkesulitan Belajar. Jakarta: PT Rineka Cipta.

Amir, M.T. (2009). Inovasi Pendidikan Melalui Problem Based learning. Jakarta: Kencana Prenada Media Group

Barrett, T et al., (2005). Handbook of Enquiry \& Problem Based Learning. Barrett, T., Mac Labhrainn, I., Fallon, H. (Eds). Galway: CELT. [Online]. Tersedia http://www.nuigalway.ie/celt/pblboo k [12 April 2013]

Bell, F. H. (1978). Teaching and Learning Mathematics. Wim. C. Brown Company Publishers. USA.

Branca, N.A. (1980). Problem Solving as Goal, Process and Basic Skills. in S Krulik and R.E. Reys (Eds). Problem Solving in School Mathematics. Washington DC: NCTM.

Dahar, R. W. (2011). Teori-Teori Belajar dan Pembelajaran. Jakarta: Erlangga.

Depdiknas. (2006). Kurikulum Standar Kompetensi Matematika Sekolah Menengah Atas dan Madrasah aliyah. Jakarta: Depdiknas.

Duch, B.J., Groh, S.E., dan Allen, D.E. (2001). Why Problem-Based Learning: A Case Study of Institutional Change in 
Undergraduate Education. Dalam B.J. Duch, S.E. Groh, dan D.E. Allen (Eds): The Power of ProblemBased Learning. Virginia, Amerika: Stylus Publishing.

National Council of Teacher of Mathematics (NCTM). (2000). Curriculum and Evaluation Standars for School Mathematics, United States of America: The National Council of Teachers of Mathematics Inc.

Nurhasanah, L. (2009). Meningkatkan Kompetensi Strategis (Strategic Competence) Siswa SMP melalui Model PBL (Problem Based Learning). Skripsi pada FPMIPA UPI Bandung: Tidak diterbitkan.

Ruseffendi, E.T. (1991). Pengajaran Matematika Modern dan Masa Kini. Tarsito: Bandung.

.(1991). Pengantar Kepada Membantu Guru Mengembangkan Kompetensinya dalam Pengajaran Matematika untuk Meningkatkan CBSA. Bandung: Tarsito

Rusman. 2012. Model-Model Pembelajaran Mengembangkan Profesionalisme Guru. Jakarta: PT RajaGrafindo Persada. (2005). Dasar-Dasar Penelitian Pendidikan dan Bidang Non-Eksakta Lainnya. Bandung: Tarsito.

(2006). Pengajaran Matematika. Bandung: Tarsito.

Sagala, S. (2011). Konsep dan Makna Pembelajaran. Bandung: Alfabeta.

Sugiyono. (2010). Statistika Untuk Penelitian. Alfabeta: Bandung.

Suhendra. (2005). Pembelajaran Berbasis Masalah dalam Kelompok Belajar Kecil untuk Mengembangkan Kemampuan Siswa SMA pada Aspek Problem Solving Matematik. Tesis
Sekolah Pasca Sarjana UPI Bandung: Tidak diterbitkan.

Sumarmo, U. (1994). Suatu Alternatif Pengajaran untuk Meningkatkan Kemmapuan Pemecahan Masalah pada Guru dan Siswa Sekolah Menengah Atas di Kodya Bandung. Laporan Penelitian UPI Bandung. Tidak Diterbitkan

- (2000). Pengembangan Model Pembelajaran Matematika untuk Meningkatkan kemampuan Intelektual Tingkat Tinggi Siswa Sekolah Dasar. Laporan Penelitian UPI. Tidak Diterbitkan.

(2013). Kumpulan Makalah Berpikir dan Disposisi Matematika serta Pembelajarannya. Jurusan Pendidikan Matematika : FMIPA UPI.

Sundayana, R. (2010). Statistika Penelitian Pendidikan. Bandung: Alfabeta.

Wahyudin. (2008). Pembelajaran dan Model-Model Pembelajaran.

Bandung: UPI

\section{RIWAYAT HIDUP PENULIS}

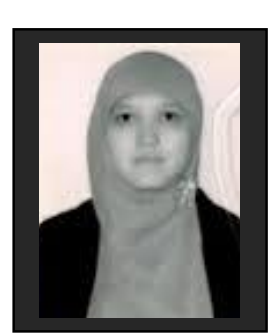

Tina Sri Sumartini, M.Pd.. Lahir di Garut, 11 Maret 1988. Dosen Tetap Yayasan di STKIP Garut. Studi S1 Pendidikan Matematika STKIP Garut, lulus tahun 2010; dan S2 Pendidikan Matematika UPI, Bandung, lulus tahun 2014. 